\title{
Resenha
}

\section{O lugar das meias: a virada lingüística da economia e seus efeitos sobre a política}

Fábio Malini*

MARAZZI, Christian. O lugar da meias: a virada lingüística da economia e seus efeitos sobre a política. Rio de Janeiro: Civilização Brasileira, 2009. 176 p.

\section{A vida na produção just in time}

Depois de dez anos, chega ao Brasil o livro "O lugar das meias", de Christian Marazzi, uma das mais importantes obras que explica as reconfigurações do capitalismo (do industrial para o cognitivo) a partir das referências teóricas do círculo pós-operaísta em nossa época. Marazzi, entre aqueles que freqüentam esse círculo, como Antonio Negri, Giuseppe Cocco, Yann Boutang, Maurizio Lazzarato, Michael Hardt, Paolo Virno, Ivana Bentes, Franco Bifo, Peter Pal Pelbart, Cesar Altamira e tantos outros, ocupa com esse livro o lugar de pioneiro no debate sobre as relações de poder inscritas nos processos de financeirização do capital.

Para Marazzi, o salto paradigmático do capitalismo industrial para o cognitivo, a "virada de época", ocorreu quando da entrada da comunicação - portanto, da linguagem - na esfera da produção. Não haveria muito mistério nisso, porque essa entrada tem relação com a redução do poder aquisitivo e do consumo das mercadorias, o que conduziu hoje a produção a "adequar-se à situação", isto é, estruturar a produção de modo a "poder aumentar o rendimento (a produtividade) sem aumentar excessivamente a quantidade produzida", escreve o economista suíço. O capitalismo cognitivo inaugura o paradigma da produção enxuta ("lean production"), em que o ritmo de produção é ditado pela produção de "pequenas quantidades de numerosos modelos de produto". É um capital-remix, recombinante, de customização massificada. Isso porque a produtividade desse capital é extraída - em tempo real, usando das tecnologias informáticas - do controle das novas demandas de consumo. Não é à toa que os departamentos de marketing passam a ditar todo o ritmo da produção do chão de fábrica. Cabe ao marketing tanto criar novas demandas, como fazer com que a indústria esteja preparada para produzi-las. As técnicas de apropriação das variações do consumo vão exigir novos valores de uso para o trabalho, como a criação, a gestão, a manipulação de informação, a produção de serviços e afetos, a adaptabilidade às mudanças repentinas; nesse sentido, a força de trabalho também passa a ser contratada "just in time": para cada nova demanda do consumo, um novo valor de uso do trabalho. O resultado é um estatuto do trabalho que beira o colapso: fragmentação do trabalho, terceirização, trabalho em tempo parcial, autônomo, trabalho por empreitada, enfim, toda uma gama de relações de trabalho de curta duração cujo principal propósito é o de responder à oferta criada pela demanda.

\footnotetext{
* Doutor em Comunicação e Cultura pela UFRJ e Professor Adjunto do Departamento de Comunicação da Universidade Federal do Espírito Santo. Travessa Lucio Bacelar 100/201, Praia da Costa, Vila Velha- Espírito Santo. CEP: 29101035. Email: fabiomalini@gmail.com
} 
Há, nesse domínio, salienta Marazzi, um nível de exploração e contradição ao mesmo tempo, porque a demanda surge por causa da comunicação instaurada no social, ou seja, das subjetividades, gostos, estilos e linguagens desejadas. Quanto maior é a socialização de conhecimentos, saberes, informação e cultura, mais rápida é a) a atualização do desejo no consumo e b) a criação de novos valores de uso para o trabalho. Nesse sentido, é o terreno da reprodução que dita o ritmo da produção num capitalismo que produzirá vida "just in time". Tal como Antonio Negri, em Fin de Siècle, Marazzi associa o fato de que a comunicação é, para o trabalhador de hoje, aquilo que o salário foi para o operário. Sem uma socialização dos instrumentos de comunicação, como o computador, a internet, a produção cultural, a multimídia, a telefonia móvel, a colaboração em rede, a cooperação linguiística, a geração de afeto, o trabalho vivo se restringe à repetição de formas e procedimentos, torna-se uma "memória mecânica". A comunicação, na verdade, a própria cidadania, é a condição para que o trabalho vivo se mantenha potente. É por isso que Marazzi reafirma a força que hoje possuem os bens imateriais no cálculo do valor acionário de uma empresa. "O que conta não são os imóveis ou as máquinas da firma, mas seus contatos e o potencial de sua estrutura de marketing, de sua capacidade de venda e de organização gerencial, além da força de invenção do pessoal empregado".

Após toda uma primeira parte que disserta sobre a virada paradigmática da economia, o economista suíço aborda como a Era Clinton moldou essa virada, a partir de uma nova forma de relação entre Estado e Mercado, radicalizando o enterro do Estado Social, por ser este "por um lado, visto como a causa do custo excessivo do trabalho (ônus sociais e carga fiscal) e, por outro, como causa do custo excessivo do dinheiro (aumento das taxas de juros para atrair poupança para a dívida pública)", analisa.

Nesse projeto clintoniano, o crédito ao consumo é mais vital do que aquele crédito à produção derivada do Estado Social. No nosso tempo, assegurar a efetividade da demanda será cda vez mais uma função privada, sobretudo, do sistema financeiro (leasing, cartão de crédito, compras a prestação, crédito consignado, etc). $\mathrm{O}$ aumento de crédito é a forma de antecipação do salário levando o consumidor a um estado constante de endividamento.

O lugar das meias" termina com um salutar debate sobre as dimensões transterritoriais do Estado, ou melhor, com uma proposta de um projeto de democracia global pós-capitalística, numa sentença perturbadora: "a crise da representação é o ponto de partida para a construção de espaços de mediação e de interpretação das regras que permitem realizar concretamente projetos de vida social", conclui. 